Sociodemographic inequalities in leisure-time physical activity and active commuting to school in Brazilian adolescents: National School Health Survey (PeNSE 2009, 2012, and 2015)

\section{Desigualdades sociodemográficas na prática de atividade física de lazer e deslocamento ativo para a escola em adolescentes: Pesquisa Nacional de Saúde do Escolar (PeNSE 2009, 2012 e 2015)}

\author{
Desigualdades sociodemográficas en la práctica \\ de actividad física durante el tiempo libre y \\ desplazamiento activo hacia la escuela en \\ adolescentes: Encuesta Nacional de Salud del \\ Escolar (PeNSE 2009, 2012 e 2015)
}

Rodrigo Wiltgen Ferreira 1

Andrea Ramirez Varela 1

Luciana Zaranza Monteiro 1,2

César Augusto Häfele 1

Simone José dos Santos 3

Andrea Wendt 4

Inácio Crochemore Mohnsam Silva 4

doi: 10.1590/0102-311X00037917

\begin{abstract}
The objective of this study was to identify inequalities in leisure-time physical activity and active commuting to school in Brazilian adolescents, as well as trends according to gender, type of school, maternal schooling, and geographic region, from 2009 to 2015. This was a descriptive study based on data from the Brazilian National School Health Survey (PeNSE) in 2009, 2012, and 2015. Students were defined as active in their leisure time when they practiced at least 60 minutes of physical activity a day on five or more of the seven days prior to the interview. Active commuting to school was defined as walking or biking to school on the week prior to the interview. The outcomes were stratified by gender, type of school, maternal schooling, and geographic region. Inequalities were assessed by differences and ratios between the estimates, as well as summary inequality indices. The 2009, 2012, and 2015 surveys included 61,301, 61,145, and 51,192 schoolchildren, respectively. Prevalence of leisure-time physical activity was $13.8 \%$ in 2009, 15.9\% in 2012, and $14.7 \%$ in 2015; the rates for active commuting to school were 70.6\%, 61.7\%, and 66.7\%, respectively. Boys showed 10 percentage points higher prevalence of leisuretime physical activity and 5 points higher active commuting to school than girls. Children of mothers with more schooling showed a mean of 10 percentage points higher prevalence of leisure-time physical activity than children of mothers with the lowest schooling and some 30 percentage points lower in relation to active commuting to school. The observed inequalities remained constant over the course of the period. The study identified socioeconomic and gender inequalities that remained constant throughout the period and which were specific to each domain of physical activity.
\end{abstract}

Correspondence

L. Z. Monteiro

Centro Universitário do Distrito Federal.

SEP/SUL EQ704/904 Conj. A, Brasília, DF 70390-135, Brasil. lucianazaranza@hotmail.com

1 Programa de Pós-graduação em Educação Física, Universidade Federal de Pelotas, Pelotas, Brasil.

2 Centro Universitário do Distrito Federal, Brasília, Brasil.

3 Programa Associado de Pós-graduação em Educação Física, Universidade de Pernambuco/Universidade Federal da Paraíba, Recife, Brasil.

4 Programa de Pós-graduação em Epidemiologia, Universidade Federal de Pelotas, Pelotas, Brasil. 


\section{Introduction}

Physical activity provides various short- and long-term benefits for adolescents' health 1 . Worldwide prevalence of physical inactivity among adolescents 13 to 15 years of age is estimated at $80.3 \% 2$. Specific data from Brazil in a sample of students from state capitals show that $56.9 \%$ of ninth-graders fail to reach current recommendations for weekly physical activity ${ }^{3}$. This scenario points to the promotion of physical activity as a major challenge for the public health field in Brazil and the world 4.

Due to the complexity and large number of associated and determinant factors of physical activity, evidence has shown that some population strata have greater opportunities for such practice 5 . Studies in developed countries show that young people with socioeconomic vulnerability have lower levels of physical activity 6,7,8. In Brazil, a cross-sectional study with data from all the state capitals and Federal District showed that children of mothers with more years of schooling and boys are more active in their leisure time when compared to children of mothers with incomplete primary schooling and girls 3 .

In this context, it is important to monitor physical activity and its sociodemographic determinants 4,9. Evidence suggests that determinants of physical activity in early childhood potentially influence the levels of leisure-time physical activity and the form of commuting in adolescence and adulthood 10,11. Although there are some studies that monitor indicators of leisure-time physical activity and commuting in adolescents at the individual level, there are still few aggregate analyses with a focus on the identification of inequalities between different population groups. The description of the existence and magnitude of sociodemographic inequalities in physical activity, as well as time trends, are relevant for monitoring this behavior at the population level, identifying populations that have historically received less attention.

The aim of this study was thus to identify inequalities in leisure-time physical activity and active commuting to school, as well as trends according to gender, type of school (public or private), maternal schooling, and geographic region in 2009, 2012, and 2015.

\section{Methodology}

\section{Study design}

This was an observational descriptive study based on data from a series of cross-sectional studies conducted by the Brazilian Institute of Geography and Statistics (IBGE) and Ministry of Health. The databases were used from the Brazilian National School Health Survey (PeNSE) for the years 2009, 2012, and 2015, with free public access on the IBGE website (http://www.ibge.gov.br). PeNSE is a schoolbased epidemiological study in which the target population consists of Brazilian children attending public and private schools.

Each edition of the PeNSE study has peculiarities in the sampling process. In the 2009 edition, the study was limited to the state capital and Federal District. The schools were grouped according to administrative jurisdiction by the public system (federal, state, and municipal) and private system. The primary sampling units were the schools and the secondary units were the classes. In each stratum, systematic sampling was performed with probability proportional to the number of schools in the stratum 12. In the 2012 edition, IBGE maintained the same methodology as in 2009 with the specific sampling plan in the state capitals and Federal District, and a specific sampling plan was designed for the set of municipalities in the interior of each geographic region, adding five more strata to the model used in 2009 13. PeNSE 201514 consisted of two independent probabilistic samples: one consisting of 9 th graders, maintaining the sampling plan from 2012, and the other with schoolchildren from the 6 th grade of primary school to the 3 rd year of secondary school. The latter aimed to provide estimates for Brazil as a whole and its major geographic regions for schoolchildren 13 to 17 years of age in the selected classes 14. Further methodological details are available in the specific reports for each edition of the survey 12,13,14. For comparability between the editions, the analyses in the current study only included data on schoolchildren in the 9th grade in the state capitals and Federal District for each of the three years of the survey. 


\section{Dependent and independent variables}

The three editions of the survey applied similar questionnaires on physical activity. The current study opted to reanalyze only specific questions on leisure-time physical activity and acitve commuting to school that were repeated in all three editions. Leisure-time physical activity included free-time activities like sports, dance, gymnastics, and weight training, and did not include physical education classes. The adolescents were asked about the frequency and duration of these activities on the seven days prior to the interview. Based on these questions, an leisure-time physical activity was generated that defined active adolescents as those with 60 minutes or more of physical activity per day on at least five days of the week prior to the interview. Active commuting to school used questions on how often the students walked or biked to and from school (on the seven days prior to the interview). Those that answered in the affirmative to these questions on at least one day of the week, regardless of the duration of commuting, were defined as active in commuting to school. Table 1 explains the questions used to construct the outcomes in each year of the survey.

Stratification variables included gender (male and female); type of school (public and private); geographic regions (North, Northeast, South, Southeast, and Central); as socioeconomic indicator, maternal schooling (none, incomplete primary, complete primary, complete secondary, complete university). The study opted to use maternal schooling as the economic indicator, since it was the most comparable variable between the survey editions. Importantly, the use of maternal schooling as a proxy for economic status is common practice in the health literature and is associated with various indicators of maternal and child morbidity and mortality 15 , including physical activity 7 .

\section{Statistical analyses}

The proportions of the variables and their respective $95 \%$ confidence intervals $(95 \% \mathrm{CI})$ were estimated by survey year. The weighting procedure was used for all the analyses according to the instructions and variables provided by each PeNSE survey. For each of the stratification variables, we measured relative and absolute inequalities (except for the geographic regions due to the absence of extreme groups or reference groups). Measures of relative inequalities were based on the division between the prevalence rates for the variables' extreme categories, while the measures of absolute inequalities were based on the subtraction between them. For the maternal schooling variable, the main socioeconomic component assessed here, two other summary indicators of inequality were assessed, the Slope Index of Inequality (SII) and the Concentration Index of Inequality (CIX) 16.

SII is an estimate of absolute inequality expressed in percentage points (varying from 0 to 100) that indicates the difference between the extreme categories, but taking the prevalence rates for the other categories into account. CIX is an estimate of relative inequality also based on the prevalence rates for all the categories. The coefficients range from -100 to 100, where 0 means absence of inequality. For both indicators, positive values indicate inequality, with higher estimates among children of mothers with more schooling, taking into account the current study's analyses. Finally, Equiplots (www. equidade.org/equiplot) were used for the graphic display of inequalities according to gender, maternal schooling, and geographic region. The analyses were performed with Stata 12.1 (StataCorp LP, College Station, USA) using the svy command to consider the sampling design.

\section{Ethical aspects}

The current study is based on public data (http://www.ibge.gov.br), and the original projects for the three surveys were approved by the National Commission on Research Ethics (CONEP): case reviews 11.537 (PeNSE 2009), 16.805 (PeNSE 2012), and 1.006.467 (PeNSE 2015). 
Table 1

Description of the variables used to construct the outcomes in each edition of the Brazilian National School Health Survey (PeNSE).

\begin{tabular}{|c|c|c|c|c|}
\hline & PeNSE 2009 & PeNSE 2012 & PeNSE 2015 & Working definition \\
\hline \multicolumn{5}{|c|}{$\begin{array}{l}\text { Leisure-time physical } \\
\text { activity }\end{array}$} \\
\hline Frequency & $\begin{array}{c}\text { IN THE LAST 7 DAYS, } \\
\text { not counting physical } \\
\text { education classes at } \\
\text { school, on how many } \\
\text { days did you practice } \\
\text { some physical activity like } \\
\text { sports, dance, gymnastics, } \\
\text { weight training, } \\
\text { martial arts, or some } \\
\text { other activity with the } \\
\text { orientation of a teacher } \\
\text { or instructor? } \\
\text { IN THE LAST } 7 \text { DAYS, } \\
\text { in your free time, on } \\
\text { how many days did you } \\
\text { practice physical activity } \\
\text { or sports without a } \\
\text { teacher or instructor? }\end{array}$ & $\begin{array}{l}\text { IN THE LAST } 7 \text { DAYS, } \\
\text { not counting physical } \\
\text { education classes at } \\
\text { school, on how many } \\
\text { days did you practice } \\
\text { some physical activity like } \\
\text { sports, dance, gymnastics, } \\
\text { weight training, martial } \\
\text { arts, or some other } \\
\text { activity? }\end{array}$ & $\begin{array}{l}\text { IN THE LAST } 7 \text { DAYS, } \\
\text { not counting physical } \\
\text { education classes at } \\
\text { school, on how many } \\
\text { days did you practice } \\
\text { some physical activity like } \\
\text { sports, dance, gymnastics, } \\
\text { weight training, martial } \\
\text { arts, or some other } \\
\text { activity? }\end{array}$ & $\begin{array}{l}\text { Leisure-time physical } \\
\text { activity at least five days } \\
\text { a week (minimum } 60 \\
\text { minutes/day) }\end{array}$ \\
\hline \multirow[t]{2}{*}{ Duration } & $\begin{array}{l}\text { NORMALLY, how long per } \\
\text { day do these activities } \\
\text { last with a teacher or } \\
\text { instructor? }\end{array}$ & $\begin{array}{l}\text { NORMALLY, how long per } \\
\text { day do these activities } \\
\text { last (sports, dance, } \\
\text { gymnastics, weight } \\
\text { training, martial arts, or } \\
\text { other activity)? }\end{array}$ & $\begin{array}{l}\text { NORMALLY, how long per } \\
\text { day do these activities } \\
\text { last (sports, dance, } \\
\text { gymnastics, weight } \\
\text { training, martial arts, or } \\
\text { other activity)? }\end{array}$ & \\
\hline & $\begin{array}{l}\text { NORMALLY, how long per } \\
\text { day do these activities } \\
\text { last without a teacher or } \\
\text { instructor? }\end{array}$ & & & \\
\hline \multicolumn{5}{|c|}{$\begin{array}{l}\text { Active commuting to } \\
\text { school }\end{array}$} \\
\hline \multirow[t]{2}{*}{ Frequency } & $\begin{array}{l}\text { IN THE LAST } 7 \text { DAYS, on } \\
\text { how many days did you } \\
\text { walk or pedal to school? }\end{array}$ & $\begin{array}{l}\text { IN THE LAST } 7 \text { DAYS, } \\
\text { on how many days you } \\
\text { walk or pedal to or from } \\
\text { school? (Not including } \\
\text { electric bicycles or riding } \\
\text { on the bike's } \\
\text { passenger seat) }\end{array}$ & $\begin{array}{l}\text { IN THE LAST } 7 \text { DAYS, on } \\
\text { how many days did you } \\
\text { walk or pedal to school? }\end{array}$ & $\begin{array}{l}\text { Commuting on foot or } \\
\text { bicycle, dichotomously } \\
\text { (active commuting IN THE } \\
\text { LAST } 7 \text { DAYS, yes or no) }\end{array}$ \\
\hline & $\begin{array}{l}\text { IN THE LAST } 7 \text { DAYS, on } \\
\text { how many days did you } \\
\text { walk or pedal back from } \\
\text { school? }\end{array}$ & & $\begin{array}{l}\text { IN THE LAST } 7 \text { DAYS, on } \\
\text { how many days did you } \\
\text { walk or pedal back from } \\
\text { school? }\end{array}$ & \\
\hline
\end{tabular}




\section{Results}

The total numbers of individuals included in the current study were 61,301 in PeNSE 2009, 61,145 in PeNSE 2012, and 51,192 in PeNSE 2015. Table 2 describes the sample by gender, geographic region, type of school, maternal schooling, and prevalence of leisure-time physical activity and active commuting to school. The highest proportions of participants in all the studies were females, students attending public schools, residents of the South of Brazil, and whose mothers had complete secondary schooling or greater. Prevalence of leisure-time physical activity was $13.8 \%$ and $14.7 \%$ in 2009 and 2015, respectively, while $70.6 \%$ of the schoolchildren in 2009 and $66.7 \%$ in 2015 reported active commuting to school.

Table 3 describes the prevalence of leisure-time physical activity stratified by year of survey and measures of absolute and relative inequalities according to the target variables. In terms of absolute inequalities, prevalence of leisure-time physical activity among boys was always at least 12 percentage points (p.p.) greater than for girls. For relative inequalities, boys showed 3.1 higher prevalence of leisure-time physical activity than girls in 2009 and 2.4 times higher in 2015. As for the different geographic regions, considering the $95 \% \mathrm{CI}$, there were no significant differences between the prevalence rates for leisure-time physical activity during the study period. As for type of school and maternal schooling, inequalities in leisure-time physical activity were found, evidencing higher prevalence of leisure-time physical activity among schoolchildren in the private school system and those whose mothers had more schooling. In relation to maternal schooling, although with a relatively low magnitude [CIX $=0.13$ (95\%CI: $0.05 ; 0.21$ ], the relative inequality was positive, expressing inequality for children of mothers with less schooling. As for absolute inequality, SII was some 10p.p. in the three years of the study, showing that adolescent children of mothers with ore schooling always showed higher mean prevalence of leisure-time physical activity.

Table 4 describes the prevalence of active communting to school stratified by year of survey and the respective measures of inequalities. Boys showed higher prevalence of active commuting to school than girls in the three surveys. The absolute differences between boys and girls in active commuting to school were 4.3p.p. in 2009, 2.9p.p. in 2012, and 6.6p.p. in 2015. As for geographic region, adolescents from the Central showed lower prevalence of active commuting to school when compared to the other regions in 2009 and 2015. Students in public schools consistently showed higher prevalence of active commuting to school. The negative values for SII and CIX show that in this case, active commuting to school was higher in children of mothers with less schooling, whose prevalence of active commuting to school was some 30p.p. higher than in children of mothers with more schooling in 2009 and 2015 [SII: -31.9 (95\%CI: -45.6; -18.2) in 2009; SII: -32.4 (95\%CI: -44.5; -20.3) in 2015]. Figure 1 shows the absolute inequalities and their time trends, stratified by maternal schooling, gender, and geographic region.

\section{Discussion}

This was a pioneering study in assessing nationwide trends in inequalities in leisure-time physical activity and active commuting to school among Brazilian adolescents according to sociodemographic characteristics. The study identified important inequalities related to gender and maternal schooling, suggesting that different contexts exert specific influences on levels of leisure-time physical activity and active commuting to school. Although there is no evidence that these inequalities are increasing, it is worrisome that the differences are not decreasing.

The results according to gender in both domains of physical activity show clear inequality over the years analyzed, since boys had higher levels of leisure-time physical activity and active commuting to school. Independently of the instrument used, evidence shows that boys are more active on average in their leisure time 5 and in commuting to and from school 17 when compared to girls. For example, Conti et al. 18 report that since early childhood, boys are encouraged to practice sports and other physical activities, while girls are more encouraged to develop typically sedentary indoor activities. In addition, a feeling of insecurity, lack of social support, and inadequate infrastructure can also induce girls to be less active in both domains 19,20,21. However, the current study detected stabilization 
Table 2

Characteristics of the sample by year of Brazilian National School Health Survey (PeNSE 2009, N =61,301; PeNSE 2012, N =61,145 and PeNSE 2015, $\mathrm{N}=51,192)$.

\begin{tabular}{|c|c|c|c|c|c|c|c|c|c|}
\hline \multirow[t]{2}{*}{ Variables } & \multicolumn{3}{|c|}{2009} & \multicolumn{3}{|c|}{2012} & \multicolumn{3}{|c|}{2015} \\
\hline & $\mathbf{n}$ & $\%$ & $95 \% \mathrm{Cl}$ & $\mathbf{n}$ & $\%$ & $95 \% \mathrm{Cl}$ & $\mathbf{n}$ & $\%$ & $95 \% \mathrm{Cl}$ \\
\hline \multicolumn{10}{|l|}{ Gender } \\
\hline Male & 28,635 & 47.5 & $46.8 ; 48.2$ & 29,393 & 49.2 & $48.5 ; 49.9$ & 24,868 & 49.2 & $48.5 ; 50.0$ \\
\hline Female & 32,666 & 52.5 & $51.8 ; 53.2$ & 31,752 & 50.8 & $50.1 ; 51.5$ & 26,324 & 50.8 & $50.0 ; 51.5$ \\
\hline \multicolumn{10}{|l|}{ Geographic region } \\
\hline North & 14,363 & 11.2 & $10.9 ; 11.5$ & 13,972 & 11.7 & $11.4 ; 12.1$ & 12,412 & 12.8 & $12.5 ; 13.1$ \\
\hline Northeast & 21,255 & 23.9 & $23.5 ; 24.3$ & 21,841 & 23.7 & $23.2 ; 24.1$ & 17,419 & 23.8 & $23.4 ; 24.3$ \\
\hline South & 11,028 & 47.0 & $46.2 ; 47.7$ & 9,715 & 45.1 & $44.4 ; 45.9$ & 8,654 & 44.6 & $43.8 ; 45.4$ \\
\hline Southeast & 6,349 & 6.8 & $6.6 ; 7.0$ & 6,147 & 7.2 & $6.9 ; 7.4$ & 4,424 & 6.0 & $5.8 ; 6.2$ \\
\hline Central & 10,416 & 11.1 & $10.8 ; 11.4$ & 9,470 & 12.3 & $12.0 ; 12.6$ & 8,283 & 12.7 & $12.4 ; 13.0$ \\
\hline \multicolumn{10}{|l|}{ Type of school } \\
\hline Private & 14,955 & 20.8 & $20.3 ; 21.3$ & 16,785 & 25.5 & $24.9 ; 26.1$ & 14,868 & 27.1 & $26.5 ; 27.8$ \\
\hline Public & 48,456 & 79.2 & $78.7 ; 79.7$ & 44,360 & 74.5 & $73.9 ; 25.1$ & 36,324 & 72.9 & $72.2 ; 73.5$ \\
\hline \multicolumn{10}{|l|}{ Maternal schooling * } \\
\hline None & 1,980 & 3.8 & $3.5 ; 4.1$ & 2,702 & 5.1 & $4.7 ; 5.4$ & 1,596 & 3.8 & $3.5 ; 4.1$ \\
\hline Incomplete primary & 13,890 & 27.9 & $27.2 ; 28.6$ & 12,255 & 25.1 & $24.4 ; 25.8$ & 7,411 & 19.3 & $18.6 ; 20.0$ \\
\hline Complete primary & 8,360 & 16.9 & $16.3 ; 17.4$ & 8,829 & 18.0 & $17.4 ; 18.6$ & 6,102 & 16.1 & $17.5 ; 16.8$ \\
\hline Complete secondary & 16,249 & 31.6 & $30.1 ; 32.3$ & 17,691 & 35.0 & $34.3 ; 35.7$ & 13,183 & 33.9 & $33.1 ; 34.7$ \\
\hline Complete university & 10,657 & 19.8 & $19.2 ; 20.4$ & 9,245 & 16.8 & $16.6 ; 17.3$ & 10,955 & 26.8 & $26.0 ; 27.6$ \\
\hline \multicolumn{10}{|l|}{ Physical activity } \\
\hline \multicolumn{10}{|c|}{ Active commuting to school } \\
\hline Yes & 42,698 & 70.6 & $70.0 ; 71.2$ & 36,759 & 61.7 & $61.0 ; 62.4$ & 32,553 & 66.7 & $66.0 ; 67.4$ \\
\hline No & 19,655 & 29.4 & $28.8 ; 30.0$ & 24,283 & 38.3 & $37.6 ; 39.0$ & 18,559 & 33.3 & $32.6 ; 34.0$ \\
\hline \multicolumn{10}{|c|}{ In leisure time ( $\geq 300 \mathrm{~min} /$ week) } \\
\hline Yes & 8,370 & 13.8 & $13.3 ; 14.3$ & 10,193 & 15.9 & $15.4 ; 16.4$ & 7,752 & 14.7 & $14.2 ; 15.3$ \\
\hline No & 53,965 & 86.2 & $85.7 ; 86.7$ & 50,796 & 84.1 & $83.6 ; 84.6$ & 43,259 & 85.3 & $84.7 ; 85.8$ \\
\hline
\end{tabular}

95\% Cl: 95\% confidence interval.

* Years of school: incomplete primary (less than 8 years), complete primary (8 years), complete secondary (11 years), complete university ( $\geq 15$ years).

in the gender inequalities in leisure-time physical activity and active commuting to school over the period, possibly due to the lack of specific strategies for population groups with lower prevalence of physical activity.

The results for prevalence of leisure-time physical activity and maternal schooling were consistent with the literature 22,23,24,25. Children of mothers with more schooling tended to have higher levels of leisure-time physical activity during the period analyzed here. One hypothesis for such results is that mothers with more schooling may know more about the benefits of a healthy lifestyle for their children's health and would likely seek more opportunities to increase their children's participation in leisure-time physical activity 26 . In addition, since maternal schooling is considered a good proxy for socioeconomic status, the results could suggest that higher purchasing power facilitates leisure-time physical activity, especially guaranteeing access to private facilities (gyms, etc.) and higher likelihood of residing in neighborhoods close to parks and city squares.

Meanwhile, the results for active commuting to school and maternal schooling were in the opposite direction of the leisure-time domain. Studies show that active commuting to school is associated with different economic indicators like low family income 27 , studying in public schools 28 , and lack of 
Table 3

Characteristics of leisure-time physical activity (300 minutes of activity, week: 5 days $\times 60$ minutes) and inequalities according to target variables in each edition of the Brazilian National School Health Survey (PeNSE 2009, $N=61,301$; PeNSE 2012, $N=61,145$ and PeNSE 2015, $N=51,192$ ).

\begin{tabular}{|c|c|c|c|c|c|c|c|c|c|}
\hline \multirow[t]{3}{*}{ Variables } & \multicolumn{9}{|c|}{ Leisure-time physical activity } \\
\hline & \multicolumn{3}{|c|}{2009} & \multicolumn{3}{|c|}{2012} & \multicolumn{3}{|c|}{2015} \\
\hline & $\mathbf{n}$ & $\%$ & $95 \% \mathrm{Cl}$ & $\mathbf{n}$ & $\%$ & $95 \% \mathrm{Cl}$ & $\mathbf{n}$ & $\%$ & $95 \% \mathrm{Cl}$ \\
\hline \multicolumn{10}{|l|}{ Gender } \\
\hline Male & 5,856 & 21.5 & $20.7 ; 22.4$ & 7,018 & 22.1 & $21.3 ; 22.9$ & 5,363 & 20.9 & $20.1 ; 21.8$ \\
\hline Female & 2,305 & 6.9 & $6.4 ; 7.4$ & 3,175 & 10.0 & $9.4 ; 10.6$ & 2,389 & 8.8 & $8.2 ; 9.4$ \\
\hline Difference & & 14.6 & & & 12.1 & & & 12.1 & \\
\hline Ratio & & 3.1 & & & 2.2 & & & 2.4 & \\
\hline \multicolumn{10}{|l|}{ Geographic region } \\
\hline North & 1,852 & 12.6 & $11.8 ; 13.4$ & 2,464 & 16.8 & $16.0 ; 17.6$ & 1,942 & 15.9 & $15.1 ; 16.8$ \\
\hline Northeast & 2,525 & 12.1 & $11.5 ; 12.7$ & 3,352 & 15.4 & $14.9 ; 16.0$ & 2,445 & 14.3 & $13.7 ; 14.9$ \\
\hline South & 1,622 & 14.7 & $13.8 ; 15.7$ & 1,575 & 15.1 & $14.1 ; 16.1$ & 1,333 & 14.0 & $13.0 ; 15.1$ \\
\hline Southeast & 927 & 14.5 & $13.5 ; 15.6$ & 1,078 & 17.7 & $16.6 ; 18.9$ & 693 & 15.5 & $14.3 ; 16.8$ \\
\hline Central & 1,444 & 14.2 & $13.5 ; 15.0$ & 1,724 & 18.1 & $17.3 ; 19.0$ & 1,339 & 16.4 & $15.5 ; 17.4$ \\
\hline \multicolumn{10}{|l|}{ Type of school } \\
\hline Private & 2,370 & 16.6 & $15.6 ; 17.7$ & 3,275 & 19.6 & $18.6 ; 20.6$ & 2,500 & 16.7 & $15.8 ; 17.8$ \\
\hline Public & 6,000 & 13.1 & $12.5 ; 13.6$ & 6,918 & 14.7 & $14.1 ; 15.2$ & 5,252 & 14.0 & $13.4 ; 14.6$ \\
\hline Difference & & -3.5 & & & -4.9 & & & -2.7 & \\
\hline Ratio & & 0.8 & & & 0.8 & & & 0.8 & \\
\hline \multicolumn{10}{|l|}{ Maternal schooling * } \\
\hline None & 180 & 9.0 & $7.1 ; 11.4$ & 312 & 11.7 & $9.8 ; 13.9$ & 184 & 11.4 & $9.2 ; 14.0$ \\
\hline Incomplete primary & 1,533 & 12.1 & $11.1 ; 13.2$ & 1,691 & 12.9 & $11.9 ; 13.9$ & 979 & 12.7 & $11.4 ; 14.0$ \\
\hline Complete primary & 1,054 & 12.6 & $11.4 ; 13.9$ & 1,417 & 15.0 & $13.8 ; 16.3$ & 895 & 13.4 & $12.1 ; 14.8$ \\
\hline Complete & 2,269 & 14.2 & $13.3 ; 15.2$ & 3,191 & 17.2 & $16.2 ; 18.1$ & 2,097 & 15.7 & $14.7 ; 16.7$ \\
\hline Complete university & 1,963 & 18.7 & $17.4 ; 20.0$ & 2,070 & 22.9 & $21.4 ; 24.5$ & 2,104 & 19.3 & $18.0 ; 20.6$ \\
\hline Difference (Q5 and Q1) & & 9.7 & & & 11.2 & & & 7.9 & \\
\hline Ratio (Q5 and Q1) & & 2.1 & & & 2.0 & & & 1.7 & \\
\hline SII & & 10.8 & $8.3 ; 13.3$ & & 13.4 & $9.9 ; 16.9$ & & 9.4 & $7.2 ; 11.6$ \\
\hline CIX & & 0.13 & $0.05 ; 0.21$ & & 0.13 & $0.07 ; 0.2$ & & 0.10 & $0.06 ; 0.14$ \\
\hline
\end{tabular}

95\%Cl: 95\% confidence interval; SII: Slope Index of linequality; CIX: Concentration Index of Inequality.

Note: total values per category do not correspond to the percentage, due to weighting.

* Years of school: Q1 - none, Q2 - incomplete primary (less than 8 years), Q3 - complete primary (8 years), Q4 - complete secondary (11 years),

Q5 - complete university ( $\geq 15$ years).

other means of transportation, like automobiles ${ }^{29}$. It is likely that for this segment of the population, active commuting is not a choice, but the only form of transportation available to the schoolchildren or their families.

Concerning socioeconomic inequalities, two different patterns were maintained over time: (1) the highest difference in prevalence of leisure-time physical activity appears to be between the two groups with the most schooling, characterizing a pattern of "top inequality" 30,31; (2) active commuting to school shows a pattern of "bottom inequality" 30,31, in which the prevalence among children of mothers with more schooling is much smaller and different from the other groups. These patterns of inequalities provide important backing for public policies. Factors associated with the groups with the highest prevalence rates can be considered important characteristics to back interventions. Meanwhile, pinpointing the groups with strikingly low prevalence rates when compared to the other groups provides important information on the necessary population focus of such interventions. 
Table 4

Characteristics of active commuting to school and inequalities according to target variables in each edition of the Brazilian National School Health Survey (PeNSE 2009, N = 61,301; PeNSE 2012, $N=61,145$ and PeNSE 2015, $N=51,192$ ).

\begin{tabular}{|c|c|c|c|c|c|c|c|c|c|}
\hline \multirow[t]{3}{*}{ Variables } & \multicolumn{9}{|c|}{ Active commuting to school } \\
\hline & \multicolumn{3}{|c|}{2009} & \multicolumn{3}{|c|}{2012} & \multicolumn{3}{|c|}{2015} \\
\hline & $\mathbf{n}$ & $\%$ & $95 \% \mathrm{Cl}$ & $\mathbf{n}$ & $\%$ & $95 \% \mathrm{Cl}$ & $\mathbf{n}$ & $\%$ & $95 \% \mathrm{Cl}$ \\
\hline \multicolumn{10}{|l|}{ Gender } \\
\hline Male & 19,764 & 72.9 & $72.0 ; 73.7$ & 18,370 & 63.2 & $62.1 ; 64.1$ & 16,680 & 70.1 & $69.1 ; 71.0$ \\
\hline Female & 21,678 & 68.6 & $67.7 ; 69.4$ & 18,389 & 60.3 & $59.3 ; 61.2$ & 15,873 & 63.5 & $62.5 ; 64.5$ \\
\hline Difference & & 4.3 & & & 2.9 & & & 6.6 & \\
\hline Ratio & & 1.1 & & & 1.0 & & & 1.1 & \\
\hline \multicolumn{10}{|l|}{ Geographic region } \\
\hline North & 10,269 & 75.7 & $74.7 ; 76.6$ & 8,731 & 62.7 & $61.6 ; 63.7$ & 8,150 & 68.4 & $67.2 ; 69.4$ \\
\hline Northeast & 14,061 & 69.1 & $68.3 ; 69.9$ & 12,557 & 59.7 & $59.0 ; 60.5$ & 11,078 & 67.2 & $66.4 ; 68.1$ \\
\hline South & 7,447 & 71.5 & $70.3 ; 72.6$ & 6,004 & 62.5 & $61.1 ; 63.9$ & 5,676 & 67.5 & $66.0 ; 68.9$ \\
\hline Southeast & 4,322 & 71.2 & $69.8 ; 72.4$ & 3,676 & 62.1 & $60.7 ; 63.5$ & 2,818 & 66.6 & $65.0 ; 68.2$ \\
\hline Central & 6,599 & 65.1 & $64.1 ; 66.2$ & 5,791 & 61.5 & $60.4 ; 62.6$ & 4,831 & 61.6 & $60.4 ; 62.7$ \\
\hline \multicolumn{10}{|l|}{ Type of school } \\
\hline Private & 6,599 & 50.8 & $49.4 ; 52.1$ & 7,237 & 48.4 & $47.2 ; 49.7$ & 6,323 & 47.2 & $45.8 ; 48.5$ \\
\hline Public & 36,099 & 75.9 & $75.2 ; 76.5$ & 29,522 & 66.3 & $65.4 ; 67.0$ & 26,230 & 74.0 & $73.2 ; 74.8$ \\
\hline Difference & & 25.1 & & & 17.9 & & & 26.8 & \\
\hline Ratio & & 1.5 & & & 1.4 & & & 1.6 & \\
\hline \multicolumn{10}{|l|}{ Maternal schooling * } \\
\hline None & 1,525 & 78.9 & $75.6 ; 81.9$ & 1,700 & 62.1 & $58.6 ; 65.5$ & 1,214 & 78.6 & $75.0 ; 81.9$ \\
\hline Incomplete primary & 10,874 & 79.6 & $78.5 ; 80.7$ & 8,264 & 67.0 & $65.5 ; 68.5$ & 5,435 & 74.7 & $73.0 ; 76.4$ \\
\hline Complete primary & 6,151 & 75.6 & $74.0 ; 77.1$ & 5,757 & 67.6 & $65.9 ; 69.2$ & 4,282 & 72.8 & $70.8 ; 74.6$ \\
\hline Complete & 10,683 & 68.0 & $66.7 ; 69.2$ & 10,698 & 62.1 & $60.8 ; 63.3$ & 8,358 & 66.6 & $65.3 ; 67.9$ \\
\hline Complete university & 5,141 & 52.4 & $50.7 ; 54.0$ & 4,081 & 49.5 & $47.6 ; 51.3$ & 4,995 & 49.8 & $48.2 ; 51.5$ \\
\hline Difference (Q5 and Q1) & & -26.5 & & & -12.6 & & & -28.8 & \\
\hline Ratio (Q5 and Q1) & & 0.7 & & & 0.8 & & & 0.6 & \\
\hline SII & & -31.9 & $-45.6 ;-18.2$ & & -15.0 & $-33.3 ; 3.3$ & & -32.4 & $-44.5 ;-20.3$ \\
\hline CIX & & -0.07 & $-0.13 ;-0.01$ & & -0.04 & $-0.10 ;-0.02$ & & -0.08 & $-0.14 ;-0.02$ \\
\hline
\end{tabular}

195\%Cl: 95\% confidence interval; SII: Slope Index of linequality; CIX: Concentration Index of Inequality.

Note: total values per category do not correspond to the percentage, due to weighting.

* Years of school: Q1 - none, Q2 - incomplete primary (less than 8 years), Q3 - complete primary (8 years), Q4 - complete secondary (11 years), Q5 complete university ( $\geq 15$ years).

The results for inequalities in leisure-time physical activity between geographic regions are similar, based on the confidence interval throughout the period analyzed. However, the prevalence of leisure-time physical activity was still low in all the regions, emphasizing the importance of programs to promote physical activity. There has doubtless been major progress in the promotion of physical activity since the implementation of the National Policy for Health Promotion ${ }^{32}$. However, physical activity programs funded by the Brazilian Ministry of Health that include the adolescent population in their proposals are still uncommon in the primary healthcare system and have low coverage, usually targeted to populations with specific conditions like obesity and type 2 diabetes ${ }^{33}$. Even physical education in schools, a mandatory component of all primary education throughout Brazil, is facing serious difficulties in attenuating this situation ${ }^{34}$. Other policies such as the School Health Program, After-School Program, and City Sports and Leisure Program also have strategies to promote physical activity, but their impacts have not been widely assessed. At any rate, one can infer that the promotion of physical activity is a key government issue, with various strategies implemented in the last fifteen 
Inequalities in leisure-time physical activity and active commuting to school, according to maternal schooling, gender, and geographic region in the Brazilian National School Health Survey (PeNSE 2009, N = 61,301; PeNSE 2012, N = 61,145 and PeNSE 2015, N = 51,192).
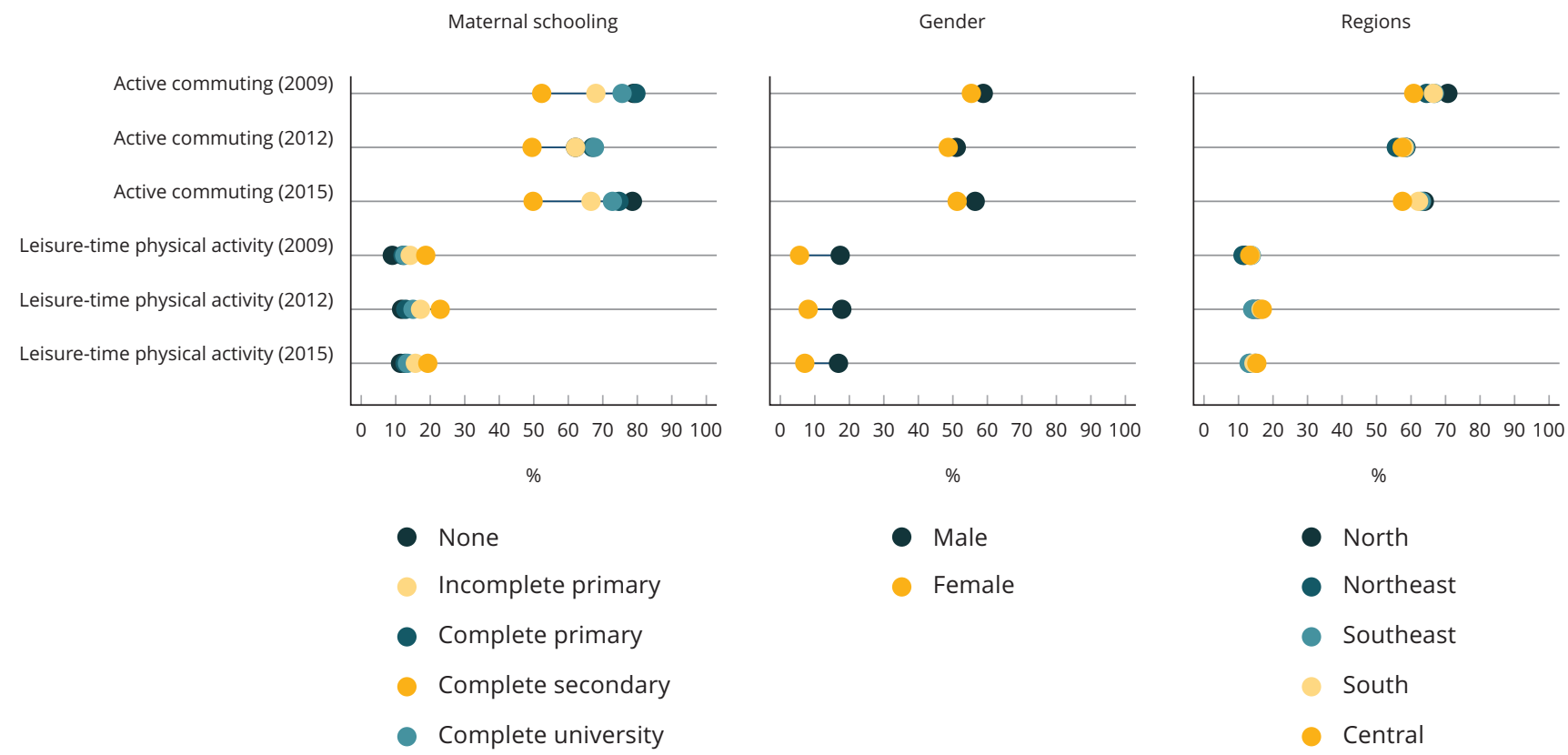

years. However, it is important for the various existing policies to combine the potential of the strategies and levels of work to converge on common objectives and targets, highlighting physical activity as a factor for health promotion rather than merely to recover from injuries 35,36 .

The results for ative commuting to school follow the tendency for leisure-time physical activity; however, the Central appears to have lower prevalence, according to the 2009 and 2015 surveys. No study was found with a sample from this region and that estimates active commuting to school. A multicenter study in 12 countries showed wide heterogeneity between the prevalence rates for active commuting to school 37 , demonstrating that socioenvironmental characteristics may be contributing to these patterns of inequalities. Safety, company for commuting 21 , and the built environment 38 have been reported as important for active commuting, especially as adolescents grow older, since when they are younger the parents fear accidents with their children on the way to school, and when the choice is possible, they end up using other forms of transportation for their kids 19,39.

Some limitations to the study deserve mention. No psychometric results of the instruments used to assess physical activity were found. Thus, the existence of information bias cannot be ruled out entirely. However, a large portion of the study instrument is based on very similar questions from the International Physical Activity Questionnaire (IPAQ) and Global Physical Activity Questionnaire (GPAQ), which have been tested and present satisfactory validity and reproducibility 40,41. Besides, the results of stratified associations and prevalence rates follow the patterns found in other studies that used questionnaires with known validity and reproducibility 42,43,44. Future studies with a focus on assessing the validity and reproducibility of these questionnaires should be encouraged. Although national surveys like PeNSE aim to monitor populations' health, there are differences in the questionnaires on physical activity that hinder comparison of the data when the questionnaires are analyzed in their totality. Thus, the current study only used questions with the greatest comparability throughout the target period (Table 1). Finally, the list of household assets differed in the three surveys, which limited 
the construction of an adequate and comparable household assets index. We thus opted to use maternal schooling as the principal socioeconomic indicator.

The study's important strengths feature the description of sociodemographic and economic inequalities in leisure-time physical activity and active commuting to school and the evaluation of their trends over time. This requires presenting both relative and absolute inequalities. In studies on trends, differences may be perceived in the measures of absolute inequalities and not identified by measures of relative inequalities. For example, if prevalence was $40 \%$ among the wealthiest and $20 \%$ among the poorest, and if prevalence later dropped to $20 \%$ in the wealthiest and $10 \%$ in the poorest, relative inequality remained the same, while absolute inequality fell by half 16 . In addition, the assessment of inequalities in maternal schooling using SII and CIX provides another possibility, since these indicators take into account all the categories of schooling and not only the extreme categories.

\section{Conclusion}

The current study's findings point to important inequalities in leisure-time physical activity and active commuting to school. For girls, the prevalence of physical activity was lower in leisure time and in commuting to school. Children of mothers with more schooling and students in private schools showed higher prevalence of leisure-time physical activity, while children of mothers with less schooling and students in public schools showed higher prevalence of active commuting to school. There was also clear stability in these inequalities from 2009 to 2015 in Brazil's state capitals and Federal District.

The detection of stability in the inequalities between boys and girls and between economic levels is worrisome. Are inequalities between genders and socioeconomic levels expected, or are they actually iniquities that need to be debated and addressed? Policymakers need to grasp this knowledge to be able to implement measures in health and the promotion of physical activity that decrease such inequalities. This requires inter-sector action involving health, education, urban planning, and public security, allowing access to the physical and social benefits of physical activity for the entire population, and especially for those most in need.

\section{Contributors}

R. W. Ferreira and A. R. Varela participated in the study project's conception, data analysis and interpretation, writing of the article, and relevant critical revision. L. Z. Monteiro contributed in the study project's conception, data analysis and interpretation, and writing of the article. C. A. Häfele and I. C. M. Silva participated in the writing and relevant critical revision of the article. S. J. Santos contributesd in the data interpretation and writing of the article. A. Wendt participated in the data interpretation, statistical analysis, and final revision of the article.

\section{References}

1. Hallal PC, Victora CG, Azevedo MR, Wells JC. Adolescent physical activity and health: a systematic review. Sports Med 2006; 36:1019-30.

2. Hallal PC, Andersen LB, Bull FC, Guthold R, Haskell W, Ekelund U, et al. Global physical activity levels: surveillance progress, pitfalls, and prospects. Lancet 2012; 380:247-57.

3. Hallal PC, Knuth AG, Cruz DKA, Mendes MI, Malta DC. Prática de atividade física em adolescentes brasileiros. Ciênc Saúde Coletiva 2010; 15:3035-42.

4. Kohl HW, Craig CL, Lambert EV, Inoue S, Alkandari JR, Leetongin G, et al. The pandemic of physical inactivity: global action for public health. Lancet 2012; 380:294-305. 
5. Bauman AE, Reis RS, Sallis JF, Wells JC, Loos RJF, Martin BW. Correlates of physical activity: why are some people physically active and others not? Lancet 2012; 380:258-71.

6. Font-Ribera L, García-Continente X, DavóBlanes MC, Ariza C, Díez E, García Calvente MM, et al. El estudio de las desigualdades sociales en la salud infantil y adolescente en España. Gac Sanit 2014; 28:316-25.

7. Stalsberg R, Pedersen AV. Effects of socioeconomic status on the physical activity in adolescents: a systematic review of the evidence. Scand J Med Sci Sports 2010; 20:368-83.

8. Taylor WC, Baranowski T, Young DR. Physical activity interventions in low-income, ethnic minority, and populations with disability. Am J Prev Med 1998; 15:334-43.

9. Kriska AM, Rexroad AR. The role of physical activity in minority populations. Womens Health Issues 1998; 8:98-103.

10. Faleiro JC, Giatti L, Barreto SM, Camelo LV, Griep RH, Guimarães J, et al. Posição socioeconômica no curso de vida e comportamentos de risco relacionados à saúde: ELSA-Brasil. Cad Saúde Pública 2017; 33:e00017916.

11. Juneau CE, Benmarhnia T, Poulin AA, Cote S, Potvin L. Socioeconomic position during childhood and physical activity during adulthood: a systematic review. Int J Public Health 2015; 60:799-813.

12. Instituto Brasileiro de Geografia e Estatística. Pesquisa Nacional de Saúde do Escolar: 2009. Rio de Janeiro: Instituto Brasileiro de Geografia e Estatística; 2009.

13. Instituto Brasileiro de Geografia e Estatística. Pesquisa Nacional de Saúde do Escolar: 2012. Rio de Janeiro: Instituto Brasileiro de Geografia e Estatística; 2013.

14. Instituto Brasileiro de Geografia e Estatística. Pesquisa Nacional de Saúde do Escolar: 2015. Rio de Janeiro: Instituto Brasileiro de Geografia e Estatística; 2016.

15. Drachler ML, Côrtes SMV, Castro JD, Leite JCC. Proposta de metodologia para selecionar indicadores de desigualdade em saúde visando definir prioridades de políticas públicas no Brasil. Ciênc Saúde Coletiva 2003; 8:461-70.

16. Barros AJ, Victora CG. Measuring coverage in $\mathrm{MNCH}$ : determining and interpreting inequalities in coverage of maternal, newborn, and child health interventions. PLoS Med 2013; 10:e1001390.

17. Santos CM, Barbosa JMV, Cheng LA, Barros MVG. Atividade física no contexto dos deslocamentos: revisão sistemática dos estudos epidemiológicos realizados no Brasil. Rev Bras Ativ Fís Saúde 2012; 14:15-22.

18. Conti MA, Frutuoso MFP, Gambardella AMD. Excesso de peso e insatisfação corporal em adolescentes. Rev Nutr 2005; 18:491-7.

19. Staunton CE, Hubsmith D, Kallins W. Promoting safe walking and biking to school: the Marin County success story. Am J Public Health 2003; 93:1431-4.
20. Timperio A, Ball K, Salmon J, Roberts R, GilesCorti B, Simmons D, et al. Personal, family, social, and environmental correlates of active commuting to school. Am J Prev Med 2006; 30:45-51.

21. Gonçalves H, Hallal PC, Amorim TC, Araújo CL, Menezes A. Fatores socioculturais e nível de atividade física no início da adolescência. Rev Panam Salud Pública 2007; 22:246-53.

22. Farias JC, Lopes AS, Mota J, Hallal PC. Prática de atividade física e fatores associados em adolescentes no Nordeste do Brasil. Rev Saúde Pública 2012; 46:505-15.

23. Sherar L, Muhajarine N, Esliger D, BaxterJones A. The relationship between girls' (8-14 years) physical activity and maternal education. Ann Hum Biol 2009; 36:573-83.

24. Wijtzes AI, Jansen W, Bouthoorn SH, Pot N, Hofman A, Jaddoe VW, et al. Social inequalities in young children's sports participation and outdoor play. Int J Behav Nutr Phys Act 2014; 11:155.

25. Pereira S, Katzmarzyk PT, Gomes TN, Borges A, Santos D, Souza M, et al. Profiling physical activity, diet, screen and sleep habits in Portuguese children. Nutrients 2015; 7:4345-62.

26. Domingues MR, Araújo CLP, Gigante DP. Conhecimento e percepção sobre exercício físico em uma população adulta urbana do sul do Brasil. Cad Saúde Pública 2004; 20:204-15.

27. Spinks A, Macpherson A, Bain C, McClure R. Determinants of sufficient daily activity in Australian primary school children. J Paediatr Child Health 2006; 42:674-9.

28. Silva KS, Lopes AS, Silva FM. Atividade física no deslocamento à escola e no tempo livre em crianças e adolescentes da cidade de João Pessoa, PB, Brasil. Rev Bras Ciênc Mov 2007; 15:61-70.

29. Tudor-Locke C, Ainsworth BE, Adair LS, Popkin BM. Objective physical activity of Filipino youth stratified for commuting mode to school. Med Sci Sports Exerc 2003; 35:465-71.

30. World Health Organization. State of inequality: reproductive, maternal, newborn and child health. Geneva: World Health Organization; 2015.

31. Victora CG, Fenn B, Bryce J, Kirkwood BR. Co-coverage of preventive interventions and implications for child-survival strategies: evidence from national surveys. Lancet 2005; 366:1460-6.

32. Malta DC, Morais Neto OL, Silva MMA, Rocha D, Castro AM, Reis AAC, et al. Política Nacional de Promoção da Saúde (PNPS): capítulos de uma caminhada ainda em construção. Ciênc Saúde Coletiva 2016; 21:1683-94.

33. Amorim T, Knuth A, Cruz D, Malta D, Reis R, Hallal PC. Descrição dos programas municipais de promoção da atividade física financiados pelo Ministério da Saúde. Rev Bras Ativ Fís Saúde 2013; 18:63-74. 
34. Soares CA, Hallal PC. Interdependência entre a participação em aulas de educação física e níveis de atividade física de jovens brasileiros: estudo ecológico. Rev Bras Ativ Fís Saúde 2015; 20:588-97.

35. Damico JGS, Knuth AG. O des(encontro) das práticas corporais e atividade física: hibridizações e borramentos no campo da saúde. Movimento 2014; 20:329-50.

36. Reis RS, Salvo D, Ogilvie D, Lambert EV, Goenka S, Brownson RC, et al. Scaling up physical activity interventions worldwide: stepping up to larger and smarter approaches to get people moving. Lancet 2016; 388:1337-48.

37. Denstel KD, Broyles ST, Larouche R, Sarmiento OL, Barreira TV, Chaput JP, et al. Active school transport and weekday physical activity in 9-11-year-old children from 12 countries. Int J Obes Suppl 2015; 5 Suppl 2:S100-6.

38. McGrath LJ, Hopkins WG, Hinckson EA. Associations of objectively measured built-environment attributes with youth moderate-vigorous physical activity: a systematic review and meta-analysis. Sports Med 2015; 45:841-65.

39. Giles-Corti B, Kelty SF, Zubrick SR, Villanueva KP. Encouraging walking for transport and physical activity in children and adolescents: how important is the built environment? Sports Med 2009; 39:995-1009.
40. Herrmann SD, Heumann KJ, Der Ananian CA Ainsworth BE. Validity and reliability of the global physical activity questionnaire (GPAQ). Meas Phys Educ Exerc Sci 2013; 17:221-35.

41. Guedes DP, Lopes CC, Guedes JERP. Reprodutibilidade e validade do Questionário Internacional de Atividade Física em adolescentes. Rev Bras Med Esporte 2005; 11:151-8.

42. Ceschini FL, Andrade DR, Oliveira LC, Araújo Júnior JF, Matsudo VKR. Prevalência de inatividade física e fatores associados em estudantes do ensino médio de escolas públicas estaduais. J Pediatr (Rio J.) 2009; 85:301-6.

43. Ekelund U, Tomkinson G, Armstrong N. What proportion of youth are physically active? Measurement issues, levels and recent time trends. Br J Sports Med 2011; 45:859-65.

44. Moraes ACF, Fernandes CAM, Elias RGM, Nakashima ATA, Reichert FF, Falcão MC. Prevalência de inatividade física e fatores associados em adolescentes. Rev Assoc Méd Bras 2009; 55:523-8. 


\section{Resumo}

O objetivo foi identificar desigualdades na prática de atividade física de lazer e deslocamento ativo para escola em adolescentes brasileiros, bem como suas tendências de acordo com o sexo, tipo de escola, escolaridade materna e regiões geográficas de 2009 a 2015. Estudo descritivo baseado em dados da Pesquisa Nacional de Saúde do Escolar (PeNSE) de 2009, 2012 e 2015. Foram considerados ativos no lazer aqueles que acumularam, no mínimo, 60 minutos por dia, em cinco ou mais dias da semana anteriores à entrevista. Para deslocamento ativo para escola, foi avaliado o transporte a pé ou de bicicleta para a escola na semana anterior à entrevista. Os desfechos foram estratificados pelo sexo, tipo de escola, escolaridade materna e regiões geográficas. As desigualdades foram avaliadas por meio de diferenças e razões entre as estimativas, bem como por índices sumários de desigualdade. Foram incluídos na PeNSE 2009, 2012 e 2015, 61.301, 61.145 e 51.192 escolares, respectivamente. A prevalência de atividade física de lazer foi 13,8\% em 2009, 15,9\% em 2012 e 14,7\% em 2015; já para o deslocamento ativo para escola, foi 70,6\%, 61,7\%, 66,7\%, respectivamente. Meninos apresentaram uma prevalência de 10 pontos percentuais (p.p.) maior de atividade física de lazer e cerca de 5p.p. no deslocamento ativo para escola do que as meninas. Escolares filhos de mães com maior escolaridade apresentaram, em média, uma prevalência de atividade física de lazer 10p.p. maior do que seu grupo extremo de comparação e cerca de 30p.p. menor com relação ao deslocamento ativo para escola. As desigualdades observadas permaneceram constantes ao longo do período avaliado. Foram identificadas desigualdades socioeconômicas e entre os sexos, que se mantiveram constantes ao longo do período analisado e que foram específicas para cada domínio de atividade física.

Atividade Motora; Monitoramento; Adolescente

\section{Resumen}

El objetivo fue identificar desigualdades en la práctica de actividad física durante el tiempo libre y desplazamiento activo hacia la escuela en adolescentes brasileños, así como sus tendencias de acuerdo con sexo, tipo de escuela, escolaridad materna y regiones geográficas desde 2009 hasta 2015. Estudio descriptivo, basado en datos de la Encuesta Nacional de Salud del Escolar (PeNSE) de 2009, 2012 y 2015. Se consideraron activos durante el tiempo libre aquellos que acumularon, por lo menos, 60 minutos al dia de actividad física durante cinco o más días a la semana anteriores a la entrevista. Para el desplazamiento activo hacia la escuela, se evaluó el transporte a pie o en bicicleta hacia la escuela durante la semana anterior a la entrevista. Los resultados se estratificaron por sexo, tipo de escuela, escolaridad materna y regiones geográficas. Las desigualdades se evaluaron mediante diferencias y razones entre las estimativas, así como por el sumario de los indices de desigualdad. Se incluyeron en el PeNSE 2009, 2012 y 2015, 61.301, 61.145 y 51.192 escolares, respectivamente. La prevalencia de actividad fisica durante el tiempo libre fue de un 13,8\% en 2009, 15,9\% en 2012 y 14,7\% en 2015; ya para el desplazamiento activo hacia la escuela, fue 70,6\%, 61,7\%, 66,7\%, respectivamente. Los niños presentaron una prevalencia de 10 puntos porcentuales (p.p.) mayor de actividad física durante el tiempo libre y cerca de 5p.p. en el desplazamiento activo hacia la escuela que las niñas. Los escolares - hijos de madres con mayor escolaridad-presentaron una prevalencia media de actividad física durante el tiempo libre 10p.p. mayor que su grupo extremo de comparación, y cerca de 30p.p. menor, con relación al desplazamiento activo hacia la escuela. Las desigualdades observadas permanecieron constantes a lo largo del período evaluado. Se identificaron desigualdades socioeconómicas y entre sexos, que se mantuvieron constantes a lo largo del periodo analizado, y que fueron específicas para cada dominio de actividad física.

Actividad Motora; Monitoreo; Adolescente

Submitted on 05/Mar/2017

Final version resubmitted on 16/Aug/2017

Approved on 28/Aug/2017 